\title{
ADIPOKINES LEVEL AND INSULIN RESISTANCE IN ABDOMINALLY OBESE PATIENTS WITH ACUTE ISCHEMIC NON-LACUNAR HEMISPHERIC STROKE
}

${ }^{1}$ Delva M., ${ }^{1}$ Lytvynenko $\mathbf{N}$.

${ }^{1}$ Department of neurology with neurosurgery and medical genetic Ukrainian medical Stomatological academy, Poltava, Ukraine

\begin{abstract}
It has been examined serum concentrations of adiponectin, leptin and insulin resistance HOMA-IR index among patients with abdominal obesity II class and normal body weight patients in the acute phase of ischemic non-lacunar (atherothrombotic and cardioembolic) hemispheric strokes. There was absence of any significant difference in adipokines concentration and insulin resistance in normal body weight patients with acute stroke. Under the conditions of acute ischemic non-lacunar hemispheric stroke, patients with abdominal obesity II class have sustained reduction of adiponectin serum level at $1^{\text {st }}$ and $10^{\text {th }}$ day after stroke and transient elevation of leptin serum level, as well as HOMA-IR index at $1^{\text {st }}$ day with subsequent return to basal values on the $10^{\text {th }}$ day. The extents of these neuroendocrine changes in abdominally obese patients have a direct association with cerebral infarction volumes. These neuroendocrine peculiarities may be, at least partly, one reason of more severe stroke in abdominally obese patients.
\end{abstract}

Key words: ischemic non-lacunar stroke, abdominal obesity, adiponectin, leptin, insulin resistance.

Introduction. Stroke induces severe or permanent disabilities to many patients and is the second most common cause of death around the world. During last decade in scientific literature there are numerous reports regarding the obesity as factor that could influence ischemic strokes severity and outcome. In particular, in previous works we have demonstrated that abdominally obese patients have significantly larger average non-lacunar hemispheric stroke volumes in comparison with normal body weight ones [17]. Obese patients (especially with abdominal obesity) have more severe strokes clinical course, slower regression of symptoms, more frequent development of various complications and, consequently, longer hospital stay [19]. Moreover we have identified that abdominally obese patients with non-lacunar cerebral infarctions have worse late functional outcomes according to modified Rankin and worse self-service according to Barthel index scale in comparison with normal body weight patients [18]. Therefore, it's necessary to identify the pathophysiological mechanisms underlying the more severe ischemic strokes in patients with abdominal obesity.

The traditional view of adipose tissue as a passive reservoir for energy storage is no longer valid. Adipose tissue is now known to express and secrete a variety of bioactive peptides - adipokines (adiponectin, leptin and many others), which act at both the local (autocrine/paracrine) and systemic (endocrine) level [9]. The role of insulin and adipokines in the pathogenesis and mechanism of stroke still remains not fully understood. However, it has been suggested a significant influence of these substances on the cerebral circulation and stroke clinical features.

Adiponectin is a major adipocytes secreted adipokine abundantly present in the circulation. Unlike most other adipokines, circulating levels of adiponectin are decreased significantly in obesity [16]. Adiponectin regulates energy homeostasis in the body through stimulation of muscle cells and increasing glucose uptake and fatty acid oxidation. Additionally, adiponectin exerts vasculoprotective, anti-inflammatory and antiatherogenic effects [1, 7].

Leptin effects on energy homeostasis (on energy intake and expenditure) via hypothalamic pathways. Adipocytes secrete leptin in direct proportion to adipose tissue mass [9].

As known, abdominal obesity is associated with insulin resistance condition and glucose metabolism impairments. Hyperglycemia is common in the early phase of stroke and has adverse effects on functional outcome [5]. But, 
insulin resistance itself, independently of glycemia, may exert a deleterious effect in acute ischemic stroke [4].

Purpose of the study was to determine blood concentrations of adiponectin, leptin and insulin resistance index among patients with abdominal obesity II class in the acute phase of ischemic non-lacunar hemispheric strokes.

Materials and methods. In the study we recruited subjects of both genders between the age of 56 and 65 years with acute ischemic non-lacunar (atherothrombotic and cardioembolic subtypes) hemispheric strokes. All patients were admitted to Poltava city hospital not later than 24 hours after stroke onset. Patients didn't have diabetes mellitus and severe co-morbidities that could influence of neurological and functional recovery (oncological diseases, convulsive syndrome, hematological diseases, cardiac, liver, kidney and respiratory insufficiencies, progressive angina pectoris, acute myocardial infarction, vascular dementia, etc). All patients didn't have infectious or inflammatory diseases and didn't use anti-inflammatory drugs during 5 days before stroke onset. Moreover, patients didn't have acute neurological episodes (according to medical records) and didn't have neuroimaging signs of previously unrecognized non-lacunar strokes.

Patient's body weight was determined with mechanical weights during hospitalization. In severe cases, body weight was measured after patient improvement, or according to patient's relatives. Body mass index (BMI) was calculated as weight in kilograms divided by the square of height in meters. Body weight categories were formed on the basis of BMI: normal body weight BMI $20.0-24.9 \mathrm{~kg} / \mathrm{m}^{2}$, obesity class II - BMI 35.0$39.9 \mathrm{~kg} / \mathrm{m}^{2}$. Waist-to-hip ratio (WHR) was calculated as a measure of abdominal obesity. Waist circumference was measured with a soft tape midway between the lowest rib and the iliac crest. Hip circumference was measured over the widest part of the gluteal region. According to World Health Organization criteria, WHR $>0.9$ in men and $>0.85$ in women were denoted abdominal obesity.

Non-lacunar stroke subtype was verified by neurovisualization. Cerebral lesion volume was estimated by calculating the approximate volume of an ellipsoid on CT scans or T-2 weighted MRI scans [3].

We examined 18 patients with abdominal obesity II class and 9 normal body weight patients with non-lacunar strokes $>20 \mathrm{~cm}^{3}$. There are reports indicating reciprocal relationship between cerebral infarction volume and adiponectin serum concentration within 24 hours after ischemic stroke [8]. Moreover, hyperglycemia following a stroke may partially reflect the intensity of cerebral lesion [14]. So, among abdominally obese patients we formed two conditionally homogenous subgroups (9 patients in each subgroup) with cerebral infarction volumes $<20 \mathrm{~cm}^{3}$ and $>20 \mathrm{~cm}^{3}$.

Table 1

Characteristics of cerebral infarction volumes

\begin{tabular}{|l|c|c|}
\hline $\begin{array}{l}\text { Cerebral infarction } \\
\text { volumes, } \mathrm{cm}^{3}\end{array}$ & $<20$ & $>20$ \\
\hline minimum volume, $\mathrm{cm}^{3}$ & 2,1 & 22,5 \\
\hline maximum volume, $\mathrm{cm}^{3}$ & 19,2 & 45,4 \\
\hline average volume, $\mathrm{cm}^{3}$ & $12,7 \pm 2,0$ & $32,6 \pm 2,9$ \\
\hline
\end{tabular}

Since abdominal obesity is associated with changed adipokines activity and insulin resistance, it was formed two control groups of conditionally healthy people (with chronic lumbalgia) without concomitant neurological and somatic pathology 9 humans with normal body weight and 9 humans with abdominal obesity II class.

In hospital stroke patients received uniform therapy (antiplatelet drugs for atherothrombotic stroke, anticoagulant drugs for cardioembolic stroke, hypotensive, metabolic, nootropic drugs, etc), physiotherapy, and massage.

Venous blood samples were collected on the admission day from the antecubital vein. The blood samples were centrifugated to obtain serum, which was rapidly frozen at $-30^{\circ} \mathrm{C}$ for subsequent analysis. We used ELISA method for assessing serum concentration of adiponectin («AssayMax Human Adiponectin ELISA Kit»), leptin («DRG ${ }^{\circledR}$ Leptin ELISA»), insulin («DRG ${ }^{\circledR}$ Insulin ELISA») according to manufacturers' instructions. Blood samples were taken at $1^{\text {st }}$ day after stroke onset and additionally at $10^{\text {th }}$ day from abdominally obese patients in fasting state. Blood samples from healthy patients were obtained in fasting state.

For insulin resistance assessment we used index HOMA-IR (Homeostasis model assessment of insulin resistance). HOMA-IR=fasting glucose $(\mathrm{mmol} / \mathrm{l}) \times$ fasting insulin $(\mu \mathrm{U} / \mathrm{ml}) / 22.5$ [12]. 
Statistical analysis was performed using the statistical package Statistica 6.0 (StatSoft). Data is shown as mean (M), standard error of mean (m), probability value (p). P-value was determined by unpaired Students $t$ test. P-value less 0.05 was taken to indicate statistical significance.

\section{Results and discussion}

Table 2

Adiponectin, leptin blood concentrations and HOMA-IR index in healthy humans

\begin{tabular}{|l|l|l|c|}
\hline & $\begin{array}{l}\text { normal body } \\
\text { weight }\end{array}$ & $\begin{array}{l}\text { abdominal } \\
\text { obesity II class }\end{array}$ & $\begin{array}{c}\mathrm{p} \\
\text { value }\end{array}$ \\
\hline $\begin{array}{l}\text { adiponectin, } \\
\mu \mathrm{g} / \mathrm{ml}\end{array}$ & $50.1 \pm 1.9$ & $42.0 \pm 2.7$ & $<0.05$ \\
\hline $\begin{array}{l}\text { leptin, } \\
\text { ng/ml }\end{array}$ & $3.4 \pm 0.8$ & $7.3 \pm 0.5$ & $<0.05$ \\
\hline HOMA-IR & $0.83 \pm 0.16$ & $2.18 \pm 0.55$ & $<0.05$ \\
\hline
\end{tabular}

Table 2 shows significantly changed adipokines activity in obese healthy humans in the form of reduction adiponectin level and elevation leptin level. Moreover, abdominal obesity is associated with significant increasing of insulin resistance indicator.

Table 3

Adiponectin, leptin blood concentrations and HOMA-IR index in normal body weight patients

\begin{tabular}{|l|c|c|c|}
\hline & $\begin{array}{c}\text { ischemic } \\
\text { stroke }\end{array}$ & controls & $\mathrm{p}$ value \\
\hline $\begin{array}{l}\text { adiponectin, } \\
\mu \mathrm{g} / \mathrm{ml}\end{array}$ & $49.0 \pm 1.3$ & $50.1 \pm 1.9$ & $>0.05$ \\
\hline leptin, $\mathrm{ng} / \mathrm{ml}$ & $4.6 \pm 0.4$ & $3.4 \pm 0.8$ & $>0.05$ \\
\hline HOMA-IR & $1.49 \pm 0.3$ & $0.83 \pm 0.16$ & $>0.05$ \\
\hline
\end{tabular}

Table 3 demonstrates absence of any significant difference in adipokines concentration and insulin resistance in normal body weight patients with acute ischemic non-lacunar stroke.

Table 4

Adiponectin blood concentration $(\mu \mathrm{g} / \mathrm{ml})$ in abdominally obese patients with non-lacunar infarctions

\begin{tabular}{|l|c|c|c|c|}
\hline \multicolumn{2}{|c|}{} & \multicolumn{2}{|c|}{ cerebral infarction } & \multirow{2}{*}{ control } \\
\cline { 3 - 4 } \multicolumn{2}{|c|}{} & $<20 \mathrm{~cm}^{3}$ & $>20 \mathrm{~cm}^{3}$ & \\
\hline $\begin{array}{l}\text { day } \\
\text { after } \\
\text { stroke }\end{array}$ & $1^{\text {st }}$ & $31.8^{*} \pm 3.6$ & $\begin{array}{c}23.4^{*} \\
* * \pm 1.5\end{array}$ & $42.0 \pm 2.7$ \\
\cline { 2 - 4 } & $10^{\text {th }}$ & $34.0^{*} \pm 2.8$ & $27.9^{*} \pm 4.2$ & \\
\hline
\end{tabular}

* - difference is significant $(\mathrm{p}<0.05)$ in comparison with the control group of abdominally obese healthy humans;

** - difference is significant $(\mathrm{p}<0.05)$ in comparison with the group of abdominally obese patients with cerebral infarctions volume $<20 \mathrm{~cm}^{3}$.

Abdominally obese patients, despite volume of cerebral lesions, have significantly decreased adiponectin level at $1^{\text {st }}$ and at $10^{\text {th }}$ day after stroke. Furthermore, obese patients with larger cerebral infarctions $\left(>20 \mathrm{~cm}^{3}\right)$ have more pronounced decline of adiponectin level. Some studies outline the potential role of the adiponectin as a biomarker inversely reflecting the extent of brain injury $[8$, 10]. But till now there are unknown mechanisms that underlie this phenomenon. In a mouse model of medial cerebral artery occlusion it has been demonstrated that adiponectin exerts a cerebroprotective action, at least in part, through an endothelial nitric oxide synthase-dependent mechanism [13]. Additionally, in other experimental study it has been shown that administration of exogenous adiponectin to rats with ischemic stroke causes reduction of brain damage via the inhibition of the release of proinflammatory factors - tumor necrosis factor- $\alpha$ and interleukin-6 [6].

Table 5 Leptin blood concentration $(\mathrm{ng} / \mathrm{ml})$ in abdominally obese patients with non-lacunar infarctions

\begin{tabular}{|l|c|c|c|c|}
\hline \multicolumn{2}{|c|}{} & \multicolumn{2}{|c|}{ cerebral infarction } & \multirow{2}{*}{ control } \\
\cline { 3 - 4 } & $<20 \mathrm{~cm}^{3}$ & $>20 \mathrm{~cm}^{3}$ & \\
\hline $\begin{array}{l}\text { day } \begin{array}{l}\text { lafter } \\
\text { stroke }\end{array} \\
\text { stro }\end{array}$ & $12.1^{*} \pm 1,1$ & $\begin{array}{c}22.3^{*} \\
* * \pm 3,8\end{array}$ & $7.3 \pm 0.5$ \\
& $10^{\text {th }}$ & $8.2 \pm 1,7$ & $11.4 \pm 3,4$ & \\
\hline
\end{tabular}

* - difference is significant $(\mathrm{p}<0.05)$ in comparison with the control group of abdominally obese healthy humans;

** - difference is significant $(p<0.05)$ in comparison with the group of abdominally obese patients with cerebral infarctions volume $<20 \mathrm{~cm}^{3}$.

Generally, in abdominally obese patients leptin level at $1^{\text {st }}$ day after stroke was significantly reduced with subsequent return to basal values on the $10^{\text {th }}$ day. Moreover, we may observe a direct association between leptin level and cerebral lesion volumes - in abdominally obese patients larger 
cerebral infarction volumes are associated with more significant increasing of leptin level at $1^{\text {st }}$ day after stroke. Leptin, beside basic function, has a lot of additional physiological effects which may exacerbate brain tissue damage: leptin modulates immune response, increases production of proinflammatory cytokines, activates sympathetic nervous system, increases blood pressure, increases platelet aggregation, etc [9]. However, on the other hand, there is evidence suggesting that an increase of leptin level during the acute phase of a stroke may act as a neuroprotective factor protecting the brain from ischemic damage by reducing oxidative stress and neuronal apoptosis [11]. In experiment it has been demonstrated that normal or elevated levels of leptin, when combined with obesity, may lead to an amplification of the injury response to ischemia-reperfusion in mice [15]. Whereas in lean mice, acute administration of leptin has been shown to confer protection against ischemiainduced cerebral infarctions. An explanation for the qualitatively different responses of lean and obese mice to leptin administration is not readily available, but it may reflect an influence of adipose tissue mass on the injury response [15].

Table 6

HOMA-IR index in abdominally obese patients with non-lacunar infarctions

\begin{tabular}{|c|c|c|c|c|}
\hline & \multicolumn{2}{|c|}{ cerebral infarction } & \multirow[t]{2}{*}{ control } \\
\hline & & $<20 \mathrm{~cm}^{3}$ & $>20 \mathrm{~cm}^{3}$ & \\
\hline \multirow{2}{*}{$\begin{array}{l}\text { day } \\
\text { after } \\
\text { stroke }\end{array}$} & $1^{\mathrm{st}}$ & $7.39 * \pm 1.96$ & $\begin{array}{l}21.26^{*} \\
* *+504\end{array}$ & \multirow[t]{2}{*}{$2.18 \pm 0.55$} \\
\hline & $10^{\text {th }}$ & $2.1 \pm 0.26$ & $2.25 \pm 0.49$ & \\
\hline
\end{tabular}

* - difference is significant $(\mathrm{p}<0.05)$ in comparison with the control group of abdominally obese healthy humans;

** - difference is significant $(\mathrm{p}<0.05)$ in comparison with the group of abdominally obese patients with cerebral infarctions volume $<20 \mathrm{~cm}^{3}$.

Our data demonstrated transient increase of HOMA-IR index under the conditions of acute stroke in the abdominally obese patients. This phenomenon may be a reflection of a more pronounced neuroendocrine stress in response to cerebral lesion in patients with abdominal obesity. In addition, as well as leptin level, mean HOMAIR index was significantly higher in patients with larger cerebral lesion volumes. These peculiarities also may be, at least partly, one reason of more severe stroke in abdominally obese patients.

Thus, abdominally obese patients under conditions of acute ischemic non-lacunar stroke have changed adipokines activity and insulin resistance parameter. These impairments have direct association with cerebral infarction volumes. Maybe, above mentioned neuroendocrine peculiarities are interdependent and constitute the syndrome of adipose tissue reaction in stroke. For example, it is known that leptin secretion by adipocytes is dependent on insulin action and, in turn, leptin inhibits the production of adiponectin [2].

Present report provides additional support to the evidence of involvement of adipokines neuroendocrine response in patients with acute ischemic stroke. Further studies are needed to link of adipokines with ischemic cerebrovascular disease.

Conclusions. 1. Under the conditions of acute ischemic non-lacunar hemispheric stroke, patients with abdominal obesity II class have sustained reduction of adiponectin serum level and transient elevation of leptin serum level as well as insulin resistance index.

2. The extents of these neuroendocrine changes have a direct association with cerebral infarction volumes.

\section{REFERNCES}

1. Arita Y., Kihara S., Ouchi N., et al. Paradoxical decrease of an adipose-specific protein, adiponectin, in obesity. Biochemical and Biophysical Research Communication 1999; 257(1): 79-83.

2. Bełtowski J. Leptin and atherosclerosis. Atherosclerosis 2006; 189: 47-60.

3. Broderick J.P., Brott T.G., Duldner J.E., et al. Volume of intracerebral hemorrhage. A powerful and easy-to-use predictor of 30-day mortality. Stroke 1993; 24: 987-993.

4. Calleja A.I., García-Bermejo P., Cortijo E., et al. Insulin resistance is associated with a poor response to intravenous thrombolysis in acute ischemic stroke. Diabetes Care November 2011; 34(11): 2413-2417. 
5. Capes S., Hunt D., Malmbrg K., et al. Stress hyperglycemia and prognosis of stroke in nondiabetic and diabetic patients: a systematic overview. Stroke 2001; 32: 2426-2432.

6. Chen B., Liao W., Xu N., et al. Adiponectin protects against cerebral ischemia-reperfusion injury through anti-inflammatory action. Brain Research 2009; 1273(1): 129-137.

7. Chen H., Montagnani M., Funahashi T., et al. Adiponectin stimulates production of nitric oxide in vascular endothelial cells. The Journal of Biological Chemistry 2003; 278(45): 4502145026.

8. Efstathiou S., Tsioulos D., Tsiakou A., et al. Plasma adiponectin levels and five-year survival after first-ever ischemic stroke. Stroke 2005; 36: 1915-1919.

9. Galic S., Oakhill J., Steinberg G. Adipose tissue as an endocrine organ. Molecular and Cellular Endocrinology 2010; 316: 129-139.

10. Jaleel A., Aqil S., Jaleel F., et al. Adiponectin and infarction size in subjects with and without cerebrovascular disease. Neurosciences (Riyadh) 2009; 14(3): 245-248.

11. Jin-Ying Z., Yi-Ling S., Jie L., et al. Leptin administration alleviates ischemic brain injury in mice by reducing oxidative stress and subsequent neuronal apoptosis. The Journal of Trauma and Acute Care Surgery 2012; 72(4): 982-991.

12. Matthews D., Hosker J., Rudenski A., et al. Homeostasis model assessment: insulin resistance and beta-cell function from fasting plasma glucose and insulin concentrations in man. Diabetologia 1985; 28(7): P. 412-419.

13. Nishimura M., Izumiya Y., Higuchi A., et al. Adiponectin prevents cerebral ischemic injury through endothelial nitric oxide synthasedependent mechanisms. Circulation. - 2008. - V. 117. - P. 216-223.

14. O’Neill P., Davis I., Fullerton K., et al. Stress hormone and blood glucose response following acute stroke in the elderly. Stroke 1991; 22: 842847.

15. Terao S., Yilmaz G., Stoke K., et al. Inflammatory and injury responses to ischemic stroke in obese mice. Stroke 2008; 39: 943-950.

16. Zhu W., Cheng K., Vanhoutte P., et al. Vascular effects of adiponectin: molecular mechanisms and potential therapeutic intervention. Clinical Science 2008; 114: 361374.

17. Дельва М.Ю., Литвиненко Н.В., Пилипенко Н.С. та інш. Нейровізуалізаційні морфометричні характеристики головного мозку в гострому періоді ішемічних інсультів в осіб з ожирінням. Вісник проблем біології та медицини 2011; 2(1): 117-119.

18. Литвиненко Н.В., Дельва М.Ю. Динаміка функціонального відновлення при ішемічних нелакунарних інсультах в каротидному басейні у осіб 3 ожирінням. Перспективи медицини та біології 2012; 4(1): 152-156.

19. Литвиненко Н.В., Дельва М.Ю., Дельва І.І. Клініко-нейровізуалізаційні характеристики гострого періоду нелакунарних гемісферальних інсультів у осіб з ожирінням. Актуальні проблеми сучасної медицини: Вісник Української медичної стоматологічної академії 2011; 11(4): 55-58.

\section{PЕЗЮМЕ}

\section{УРОВНИ АДИПОКИНОВ И СОСТОЯНИЕ ИНСУЛИНОРЕЗИСТЕНТНОСТИ ПРИ ИШЕМИЧЕСКИХ НЕЛАКУНАРНЫХ ГЕМИСФЕРАЛЬНЫХ ИНСУЛЬТАХ У ПАЦИЕНТОВ С АБДОМИНАЛЬНЫМ ОЖИРЕНИЕМ}

\section{Дельва М.Ю., Литвиненко Н.В.}

Кафедра нервных болезней с нейрохирургией и медицинской генетикой Украинская медицинская стоматологическая академия, Полтава, Украина

Изучены уровни адипонектина, лептина сыворотки крови, а также индекс инсулинорезистентности HOMA-IR при ишемических нелакунарных (атеротромботических и кардиоэмболических) инсультах у пациентов с нормальной массой тела и с абдоминальным ожирением II ст. Уровни адипокинов и значения индекса HOMA-IR не изменяются у пациентов с 
нормальной массой тела. $\mathrm{y}$ пациентов с абдоминальным ожирением II ст. наблюдается стойкое снижение уровня адипонектина в 1-е и на 10-е сутки после инсульта, а также транзиторное повышение уровня лептина сыворотки крови и индекса HOMA-IR в 1-е сутки заболевания с последующим возвратом к базальным значениям на 10-е сутки. Степень выраженности этих нейроэндокринных изменений имеет прямую ассоциацию с объемами церебральных инфарктов. Данные нейроэндокринные феномены могут быть одним из факторов более тяжелого клинического течения и недостаточного функционального восстановления при нелакунарных инсультах у пациентов с абдоминальным ожирением.

Ключевые слова: ишемический нелакунарный инсульт, абдоминальное ожирение, адипонектин, лептин, инсулинорезистентность.

\section{XÜLASə}

\section{ABDOMINAL PIYLONMOLI PASIYYNTLORDO İŞEMIK QEYRİ- LAKUNAR HEMISFERAL INSULTLAR ZAMANI ADIPOKINLORIN SOVIYYOSİ VO INSSULINREZISTENTLIYIIN VOZIYYOTİ}

\author{
Delva M.Yu., Litvinenko N.V. \\ Ukrayna tibbi stomatoloji akademiyasinın \\ Neyrocarrahiyya vo tibbi genetika ila birga sinir \\ xastaliklori kafedrası, Poltava, Ukrayna
}

II dərəcə piylənməsi olan və normal bədən çəkisinə malik pasiyentlərdə işemik, qeyri-lakunar insultlar zamanı (aterotrombotik və kardioembolik) qan zərdabında adiponektinin, leptinin səviyyəsi, həm də HOMA-IR insulinrezistentlik indeksi tədqiq edilmişdir. Normal bədən kütləsinə malik pasiyentlərdə adipokinlərin səviyyəsi və HOMA-IR indeksi dəyişmir. İnsultdan sonra 1 və $10-\mathrm{cu}$ sutkalarda II dərəcəli abdominal piylənməsi olan pasiyentlərdə adipokinlərin səviyyəsinin əhəmiyyətli dərəcədə azalması, həm də xəstələnmədən sonra birinci sutkada leptinin səviyyəsinin və HOMA-IR indeksinin əhəmiyyətli dərəcədə tranzitor artması və sonra 10-cu sutkada bazal göstəricilərə qayıtması müşahidə edilmişdir.
$\mathrm{Bu}$ neyroendokrin dəyişikliklərin biruzə olunma dərəcəsi serebral infarktların həcmi ilə birbaşa əlaqətə malikdir. Göstərilmiş endokrin fenomenlər abdominal piylənməsi olan pasiyentlərdə qeyrilakunar insultlar zamanı daha ağır kliniki gedişin və funksiyaların bərpa olunmasının çatmamazlığ faktorlarından biri ola bilər.

Açar sözlər: işemik qeyri-lakunar insult, abdominal piylənmə, adiponektin, leptin, insulinrezistentlik 